(c) 2006 Plant Management Network.



Accepted for publication 8 December 2005. Published 12 January 2006.

\title{
First Report of Powdery Mildew of Gaillardia x grandiflora (Blanket Flower) Caused by Leveillula taurica in North America
}

Dean A. Glawe, Plant Pathologist, Puyallup Research and Extension Center, 7612 Pioneer Way East, Washington State University, Puyallup 98371-4998; Gary G. Grove, Associate Plant PathologistExtension Plant Pathologist, and Mark Nelson, Research Tech Supervisor, Irrigated Agriculture Research and Extension Center, Washington State University, Prosser 99350-8694

Corresponding author: Dean A. Glawe. glawe@wsu.edu

Glawe, D. A., Grove, G. G., and Nelson, M. 2006. First report of powdery mildew of Gaillardia $\times$ grandiflora (blanket flower) caused by Leveillula taurica in North America. Online. Plant Health Progress doi: 10.1094/PHP-2006-0112-01-BR.

Gaillardia $\times$ grandiflora Van Houtte. (Blanket flower) (Asteraceae) is an herbaceous perennial planted in landscapes for its colorful flowers. During recent surveys of field-grown plants at a propagation facility in Yakima Co., WA, a powdery mildew disease was observed on the cv. 'Baby Cole.' The powdery mildew fungus in question was determined to be Leveillula taurica (Lév.) G. Arnaud, previously unknown from Gaillardia species in North America. This report documents the occurrence of L. taurica on Gaillardia $\times$ grandiflora and provides information on disease symptomatology as well as features distinguishing this fungus from other powdery mildew pathogens of Gaillardia in North America.

Disease symptoms included chlorotic regions on leaves that occasionally became necrotic (Fig 1A). Diseased leaves became covered with whitish accumulations of conidiophores and conidia (Figs. 1B and 2). Conidiophores (Fig. 3) emerged in groups of 2 to 8 through stomata, were multiseptate, measured (79-) 82-163 (-184) × (5.5-) 6-8 (-9) $\mu \mathrm{m}$ and bore single conidia. Conidia were either lanceolate or cylindrical (Fig. 4) and measured (45.5-) 50.5$68.5(-73) \times(15-)$ 17-20.5 (-22) $\mu \mathrm{m}$. The teleomorph was lacking. Diagnostic characteristics indicative of $\mathrm{L}$. taurica included internal mycelium with conidiophores emerging through stomata, dimorphic conidia (lanceolate firstformed conidia and cylindrical to ellipsoid later-formed conidia), and the host genus (1).
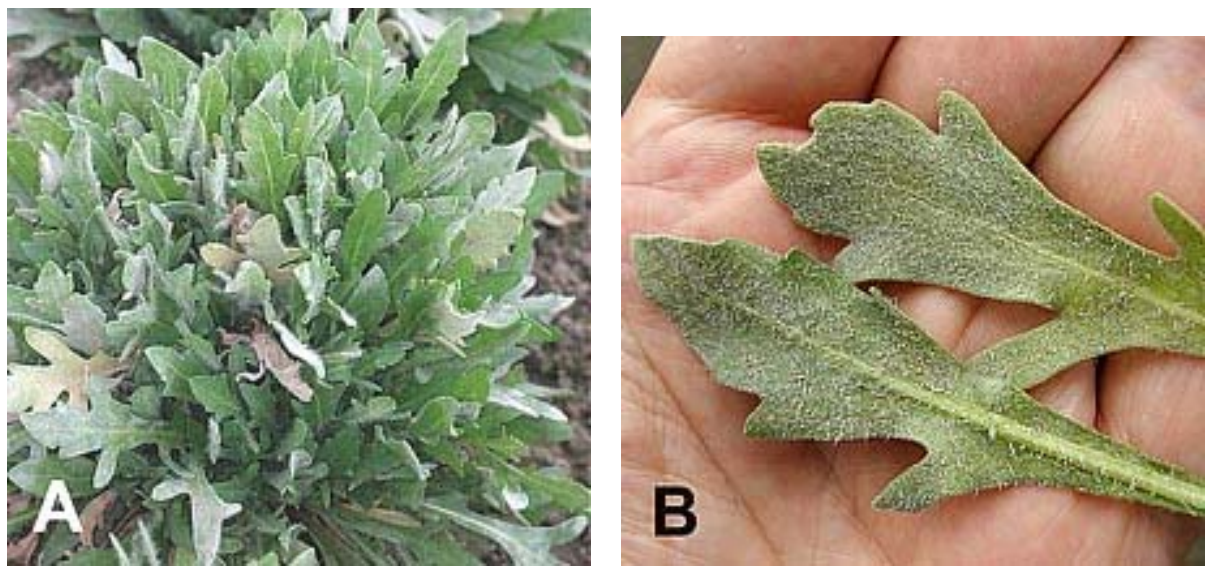

Fig. 1. Powdery mildew symptoms caused by L. taurica on Gaillardia X grandiflora.

A. Diseased plant in field. B. Infected leaves showing adaxial surface (top) and abaxial surface (bottom). 


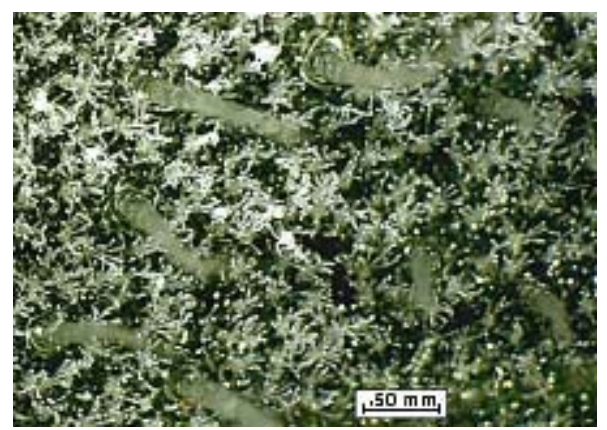

Fig. 2. Conidiophores produced by L. taurica on Gaillardia $\times$ grandiflora.

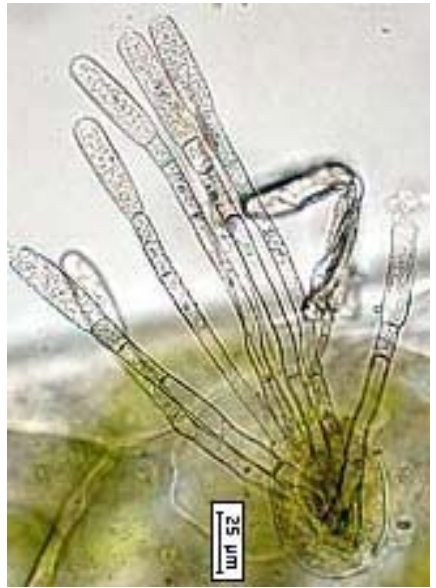

Fig. 3. Conidiophores of $\mathrm{L}$. taurica emerging through a stoma on a leaf of Gaillardia $\times$ grandiflora.

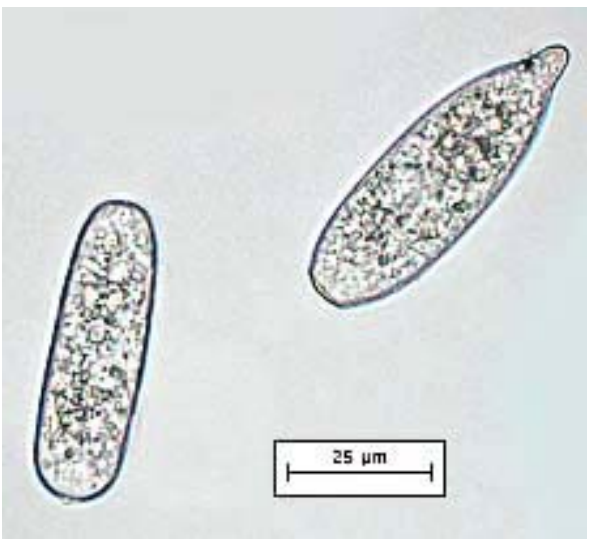

Fig. 4. Cylindrical (left) and lanceolate (right) conidia produced by L. taurica on Gaillardia $\times$ grandiflora.

Leveillula taurica previously was reported from other species of Gaillardia in south Asia, the Mediterranean region, South Africa, and the former USSR (2). In North America, reports of powdery mildew diseases of Gaillardia species implicated Erysiphe cichoracearum DC. [more recently designated Golovinomyces cichoracearum (DC.) VP Gelyuta] in Montana and Oklahoma, and Sphaerotheca [Podosphaera (sect. Sphaerotheca)] species in Montana, Oregon, Washington, and Wyoming (2). Microscopically, L. taurica is distinguished readily from other species which produce monomorphic conidia in chains from conidiophores formed on ectophytic mycelia.

Leveillula taurica first was determined to occur in Washington in 2004 on Allium cepa L., Solanum tuberosum L., and Triglochin maritima L. (5). The fungus also occurs in Idaho and British Columbia $(3,4,6)$. Within the Pacific Northwest, the only known teleomorphic host remains greenhouse-grown $\mathrm{T}$. maritima plants in eastern Washington (5). Because of the very broad host range of L. taurica (1), it is possible that hosts other than Gaillardia were the source of inoculum for the observed disease outbreak. It would be useful to determine whether perennial hosts such as Gaillardia species could be involved in overwintering of the fungus in the absence of the teleomorph.

The fungus caused significant losses, estimated at more than $25 \%$ of production, at the location studied by making infected plants unsuitable for use in propagation. Further research is needed to assess more fully the host and geographical ranges of L. taurica in the Pacific Northwest, and the possible role of multiple hosts in the epidemiology of the diseases it causes. 
Literature Cited

1. Braun, U. 1987. A monograph of the Erysiphales (powdery mildews). Beih. Nova Hedwigia 89:1-700.

2. Farr, D. F., Rossman, A. Y., Palm, M. E., and McCray, E. B. 2005. Online. Fungal Databases, Systematic Botany \& Mycology Laboratory, ARS, USDA.

3. Cerkauskas, R. F, and Buonassisi, A. 2003. First report of powdery mildew of greenhouse pepper caused by Leveillula taurica in British Columbia, Canada. Plant Dis. 87:1151.

4. Forster, R. L. 1989. Powdery mildew of greenhouse cucumbers and tomatoes caused by Leveillula taurica in Idaho. Plant Dis. 73:1020.

5. Glawe, D. A., Dugan, F. M., Liu, Y., and Rogers, J. D. 2005. First record and characterization of a powdery mildew (Erysiphales) on a member of the J uncaginaceae: Leveillua taurica on Triglochin maritima. Mycolog. Prog. 4:291298.

6. Mohan, S. K., and Molenaar, N. D. 2005. Powdery mildew caused by Leveillula taurica on glossy leaf genotypes of onion in Idaho. Plant Dis. 89:431. 